Publisher: African Networks on Ethnomedicines

Web page: /http://journals.sfu.ca/africanem/index.php/ajtcam/index

http://dx.doi.org/10.4314/ajtcam.v9i3.3

\title{
USE OF TRADITIONAL VETERINARY MEDICINE IN NHEMA COMMUNAL AREA OF THE MIDLANDS PROVINCE, ZIMBABWE
}

\author{
Alfred Maroyi \\ Biodiversity Department; School of Molecular and Life Sciences; University of Limpopo; Private Bag X1106; \\ Sovenga 0727; South Africa. \\ *Email: alfred.maroyi@ul.ac.za
}

\begin{abstract}
This study documents the use of ethno-veterinary medicine to treat livestock in Nhema communal area in the Midlands province of Zimbabwe. This study employed oral interviews and detailed discussions with 69 smallholder farmers and 3 traditional healers. The local people use 23 plant species belonging to 16 families as ethno-veterinary remedies. Two plant families were particularly frequent in usage: Fabaceae and Solanaceae, while the most utilized plant species were Aloe chabaudii (UV $=0.69)$, Aloe greatheadii ( $\mathrm{UV}=0.65)$, Adenium multiflorum $(\mathrm{UV}=0.63)$, Vernonia amygdalina $(\mathrm{UV}=0.61)$, Nicotiana tabacum $(\mathrm{UV}=56)$, Solanum lycopersicum (UV = 55), Capsicum annum ( $\mathrm{UV}=53)$ and Pouzolzia hypoleuca $(\mathrm{UV}=51)$. Fourteen animal conditions were identified in the surveyed area. The major and most common animal diseases were tick-borne diseases, eye problems, retained afterbirth, fleas, lice and diarrhoea. The majority of ethno-veterinary remedies (78\%) were collected from the wild, with respondents mostly using herbs (11 species, $48 \%$ ), followed by 6 trees $(26 \%), 4$ shrubs $(17 \%)$, and 2 climbers $(9 \%)$. The most frequently used plant parts were leaves $(51 \%)$, followed by bark $(16 \%)$, roots $(13 \%)$ and fruits $(10 \%)$. These remedies were mostly administered as decoctions or infusions of single plants. These plants were used not only as alternatives to conventional veterinary drugs but also because in certain diseases they were thought to be more efficacious. In view of many and widespread uses of wild plants as ethnoveterinary remedies, further research into their pharmacological activities may prove worthwhile.
\end{abstract}

Key words: Ethno-veterinary medicine, indigenous knowledge, traditional animal health care, Zimbabwe

\section{Introduction}

Ethno veterinary medicine or traditional animal health care is based on folk beliefs, traditional knowledge, skills, methods and practices used for curing diseases and maintaining health of animals (Mathias-Mundy and McCorkle, 1989). Ethno-veterinary medicine is gaining popularity in developing countries because it is readily accessible, easy to prepare and administer; and available at little or no cost to the farmer (Tabuti et al., 2003; Njoroge and Bussmann, 2006). In many poor rural areas, ethno veterinary medicine can play an important role in animal production and livelihood development, and often becomes the only available means for farmers to treat ill animals (McCorkle, 1986; Tomboura et al., 2000; Dold and Cocks, 2001; Matekaire and Bwakura, 2004; Jabbar et al., 2005; Mwale et al., 2005; Maine et al., 2009; Shen et al., 2010). This kind of herbal medicine provides a valuable alternative to and complements the western veterinary drugs. Traditional veterinary medicine knowledge like all other traditional knowledge systems is handed down orally from generation to generation and it may disappear because of rapid cultural, socioeconomic, environmental and technological changes (Mathias-Mundy and McCorkle, 1989; Tabuti et al., 2003; Njoroge and Bussmann, 2006). There is need therefore, to document this local knowledge of ethno-veterinary healing and conserve it through systematic studies before it is lost forever (Tabuti et al., 2003). In addition to this, diseases of livestock potentially have severe economic impacts in terms of production losses following mortality and morbidity, particularly in the case of cultures where animals are equated to wealth (McGaw and Eloff, 2008).

For the majority of rural farmers in Zimbabwe, the conventional veterinary drugs have become very expensive and therefore unaffordable, causing them to seek low cost traditional veterinary medicines (Matekaire and Bwakura, 2004; Matekaire et al., 2005; Mwale et al., 2005; Mwale et al., 2007). Rural populations in Zimbabwe have accumulated substantial traditional veterinary knowledge essential for animal health care (Gelfand et al., 1985). Despite the increasing acceptance of traditional ethno-veterinary medicine in Zimbabwe (Matekaire and Bwakura, 2004; Mwale et al., 2005), this rich indigenous knowledge on traditional ethnoveterinary remedies is not adequately documented. Documentation of plants used in ethno-veterinary practices is urgent so that the knowledge can be preserved, plants conserved and sustainably managed and utilized for the control of livestock diseases (Njoroge and Bussmann, 2006). The current investigation therefore, attempts to fill some of the gaps in indigenous knowledge related to the use of plant species as ethno-veterinary remedies in Zimbabwe, emphasizing their role in basic livestock health care.

\section{Materials and Methods Study area}

This paper is based on a case study in Nhema communal area (Figure 1), centrally located in the Midlands Province of Zimbabwe. Nhema communal area lies between $19^{\circ} 57^{\prime} \mathrm{S}$ to $20^{\circ} 30^{\prime} \mathrm{S}$ latitude and $30^{\circ} 00^{\prime} \mathrm{E}$ to $30^{\circ} 58^{\prime} \mathrm{E}$ longitude. This district is categorized as one of the most severely deforested and densely populated areas in the country (Whitlow, 1980; McGregor, 1994). It is about $1200 \mathrm{~m}$ above sea level, with a mean annual rainfall of $700 \mathrm{~mm}$, concentrated in the rainy season from November to March. In 
Publisher: African Networks on Ethnomedicines

Web page: /http://journals.sfu.ca/africanem/index.php/ajtcam/index

http://dx.doi.org/10.4314/ajtcam.v9i3.3

the hottest month, October, the mean temperature is $29^{\circ} \mathrm{C}$, and in the coldest month, July, the mean temperature is $9^{\circ} \mathrm{C}$. Severe midseason dry spells and an unreliable start to the rainy season make the area marginal for maize, tobacco and cotton. Rainfall is the greatest physical constraint to agricultural production, falling during a single rainy season. The risk of crop failure due to drought is high. Soils are largely derived from granitic-gneissic rocks, giving rise to predominantly sandy soils, with a low water-holding capacity, low fertility, low pH, and deficiencies in nitrogen, phosphorus, and sulphur (Grant, 1981; McGregor, 1994). The most extensive vegetation type is drier miombo woodland (Wild and Barbosa, 1968), in which Brachystegia spiciformis and Julbernardia globiflora are dominant in terms of basal area, with patches of Hyparrhenia spp., Eragrostis spp., Heteropogon spp. and Digitaria spp. grasses.

The majority of Nhema communal area inhabitants generate their livelihood through a mixture of agricultural activities centred on crop and livestock enterprises; with land and livestock being the primary household assets. Agricultural mechanization is relatively low, with most farmers using hand-tools. Other principal assets include ploughs, ox-drawn carts, wheelbarrows, axes, hoes, etc. Use of chemical fertilizer and improved seeds is becoming increasingly common, especially among relatively affluent residents. They grow millet, sorghum, maize, groundnuts, cowpeas, a wide range of vegetables and other legumes mainly for their own consumption. The residents are traditionally cattle, donkey, goat and sheep herders and grazing land is an important asset to them. Typically each household has about 2-5 cattle, although there are some cattle owners with much larger herds. They use cattle and donkeys to plough farms, and as a means of transporting people and goods to and from the local markets. Cattle, goats, sheep and chicken are an important source of proteins (milk and meat) and cash. Residents also use cow, goat and sheep dung as fertilizer and as a source of household energy.

\section{Data collection}

Prior to any contact with the local people, the study and its objectives were introduced to the local traditional leaders and the state veterinary officers explaining the purpose of the research. The study was aimed at documenting livestock diseases known in the study area, use of ethno-veterinary plant remedies in treating these diseases, and general ethno-veterinary medicinal knowledge held by the residents. Once the traditional leaders granted permission to proceed, I approached individuals for participation. The individuals were selected using wealth ranking (Grandin, 1988) to ensure that different wealth categories were represented in the study. Individual oral interviews were thereafter conducted with 72 smallholder farmers between May 2008 and March 2009 at different communal dip tanks. A total of three (3) traditional healers identified using the Participatory Rural Appraisal (PRA) approach (Martin, 1995), were interviewed in February 2009. Members of the local community were asked to give the names of the most renowned traditional healers in the study area. The traditional healers were professional practitioners who medicated the local people using ethnomedicinal plants and their products. An interview was also held with a professional veterinarian (see acknowledgements) in March 2009 to confirm diseases referred to by the farmers. Verbal informal consent was obtained from each individual who participated in the study. The interviews and discussions were carried out in the local language since the author is a native speaker of the language. A feedback session attended by 43 people was organized in March 2009 in order to correct, harmonize and share the information among the respondents.

\section{Plant collection and identification}

Plants said to be used as ethno-veterinary remedies during the interviews were identified in the field by the respondents. Voucher specimens were collected during walks with respondents when encountered for the first time and again when they were flowering or fruiting, for easy identification. Specimens were processed using standard taxonomic procedures (Bridson and Forman, 1998; Victor et al., 2004). Each specimen included important parts such as leaves, stems, flowers and fruits where available. For small herbaceous plants, the whole plants were collected. Specimens were deposited for future reference at the National Herbarium, Harare (SRGH, abbreviations according to Holmgren and Holmgren (2004)).

\section{Data analysis}

The majority of the data collected in this study were descriptive in nature; therefore, they were explained directly. Interview data were coded and sorted into themes. Inconsistencies and unique statements were noted and given particular attention. The data were organized and analyzed with the SPSS program (Norusis, 1988; SPSS, 1999). Information gathered through interviews was presented using percentages and ranking. The ethno-veterinary remedy importance of each plant species was assessed using its usevalue (UV) as defined by Phillips et al. (1994):

$\mathrm{UV}=\Sigma \mathrm{U} / \mathrm{n}$

where: UV is the use-value of a species; $\mathrm{U}$ is the number of citations of that species; and $n$ is the number of informants.

Only current uses were included in the calculation of the use values to reflect the realized value. In order to satisfy statistical independence requirement, participants interviewed during group discussions were not included.

\section{Results and discussion \\ Respondents' characteristics}

Most of the respondents $(61 \%)$ were males above the age of 40 (Table 1). However, a considerable number of young male and females participated in individual interviews at the dip tanks. Nine livestock species were reported in the study area, including two 
Publisher: African Networks on Ethnomedicines

Web page: /http://journals.sfu.ca/africanem/index.php/ajtcam/index

http://dx.doi.org/10.4314/ajtcam.v9i3.3

draught-power species (cattle and donkeys), four types of poultry (chicken, guinea fowl, pigeon and turkey), two small ruminants (goats and sheep) and rabbits kept as sources of meat. Cattle and goats were owned by all respondents. Chickens were the most numerous (Table 1). The study showed variations in the distribution of livestock ownership by gender. The general pattern showed that men owned more cattle and donkeys than women (Table 1). Cattle and chickens were the main livestock species in the study area. Only a few people raised sheep and rabbits. However, goats, chicken, sheep, guinea fowl, pigeon, rabbits and turkeys were mainly owned by women (Table 1) compared to men. Ownership of different species of livestock is regarded as typical of most smallholder farmers in Zimbabwe, where farmers do not concentrate on one type of livestock (Mwale et al., 2005). This is done mainly to spread the risk and to take advantage of the natural interrelationships between different livestock species.

\section{Common diseases among livestock}

Of the total of 14 livestock diseases recorded in the study area (Table 2), cattle were mostly affected by tick-borne diseases $(81.3 \%)$, eye problems $(68 \%)$ and retained afterbirth $(56 \%)$. Chickens were mostly affected by fleas $(70.7 \%)$ and diarrhoea $(59 \%)$. Foot rot was the most common disease in both goats $(54.7 \%)$ and sheep (52\%). According to respondents, cattle were the most commonly treated, followed by chickens, goats and sheep. On an overall basis, ectoparasites were more frequently reported compared with endoparasites (Table 2). In cattle, ticks were the most frequently reported by the respondents $(\mathrm{n}=61 / 75 ; 81.3 \%)$, followed by fleas infestation in chicken $(\mathrm{n}=53 / 75 ; 70.7 \%)$, lice infestation in rabbits $(\mathrm{n}=4 / 7 ; 57.1 \%)$, fleas infestation in rabbits $(\mathrm{n}=3 / 7 ; 42.9 \%)$, tick infestation in goats $(n=26 / 75 ; 34.7 \%)$ and lice infestation in chickens $(n=21 / 75 ; 28 \%)$. Ticks, fleas and lice were also removed by hand in some cases. Ticks, fleas and lice are usually a nuisance to livestock owners, and therefore easier to recognize due to their presence on the outside of the animal's body. Tick bites were recognized as the biggest causes of wounds in cattle. Heavy rains increased tick activities and respondents were not consistent in dipping their cattle due to lack of dipping chemicals. Ticks are recognized as important vectors of several economically important ailments such as heart water, anaplasmosis, sweating sickness and babesiosis, and ethno-veterinary medicine may play a significant role in the management of such diseases in a cost-effective and accessible manner (McGaw and Eloff, 2008).

The respondents faced difficulties in differentiating between internal parasitic diseases (e.g., tapeworms, trematodes, nematodes) and haemoparasitic diseases from the prevalent coccidiosis. All these were generally regarded as the main causes of diarrhoea with some respondents differentiating it into blood or watery diarrhoea. Coccidiosis is a protozoal disease responsible for deaths and lowered production in small ruminants and poultry (Matekaire et al., 2005). The symptoms of intestinal coccidiosis which include weight loss, soft to watery faeces, blood in faeces, dehydration, increased thirst, and sometimes death were all regarded as symptoms of diarrhoea or blood diarrhoea. Respondents relied on visual, audio and tactile senses to establish a diagnosis and on rare occasions post-mortem examination was employed to confirm cause of death of the livestock. According to Matekaire and Bwakura (2004), traditional healers have less to offer in the treatment and control of epidemic and endemic infectious diseases like foot and mouth disease, rinderpest, septicemia, anthrax, and acute life-threatening bacterial diseases, they can cope with a reasonable spectrum of common diseases such as diarrhoea, wounds, colds, worms, coccidiosis, and reproductive disorders. Similarly, King and Tempesta (1994) found that over the past several decades, medical ethnobotany has emerged as a new, or more appropriately revived, interdisciplinary approach to drug discovery, involving collaboration between a Western trained, physician-ethnobotanist team and indigenous healers. The establishment of such a team permits the physician to interact with the native healers in evaluation of the clinical diagnosis, while at the same time the ethnobotanist can identify the plants being used as medicines (King and Carlson, 1995). According to McGaw and Eloff (2008), only a small percentage of ethno-veterinary medicinal plants have been analysed for biological activity or toxic effects, and hence research in this field offers fertile possibilities for future investigation.

\section{Plant species used to treat livestock diseases}

This study recorded twenty three (23) plant species as useful in traditionally managing various diseases of livestock in Nhema communal area (Table 3). These medicinal plants were distributed among 16 families. The number of plant species most frequently used were cited as: Fabaceae (4), Solanaceae (4) and Asphodelaceae (2). Other families were represented by one species each, as shown in Table 3. Fabaceae and Solanaceae families have the highest diversity of species used to treat livestock diseases probably because these are large families characterized by several species. The species Aloe chabaudii, Aloe greatheadii, Musa paradisiaca, Nicotiana tabacum, Pouzolzia hypoleuca and Sarcostemma viminale were used to treat more than one livestock ailment. All plant species used as ethno-veterinary medicine are also used to treat human diseases (Gelfand et al. 1985). Use of similar plants to cure both animal and human diseases is a common practice in traditional medicine (Tabuti et al., 2003). Some of the plants inventoried here had other uses in the community; for example, Albizia amara, Parinari curatellifolia, Pseudolachnostylis maprouneifoli and Pterocarpus angolensis were also used as dye, food, firewood and for construction purposes.

Other non-plant materials such as soot and snail shell were also used as ethno-veterinary remedies. Shell was ground to powder and applied to the eye, usually two times everyday as a remedy for eye problems. These results correlate strongly with the findings of Matekaire and Bwakura (2004), who recorded grounded snail shell as a remedy for eye problems. The same authors documented the use of soot and table salt decoction as a remedy for bloat.

Analysis of the growth forms of the plants used as ethno-veterinary remedies revealed that herbs constituted the largest number or proportion with 11 species (48\%), followed by 6 trees (26\%), 4 shrubs (17\%), and 2 climbers (9\%) as shown in Figure 2 A. The majority of plants used as ethno-veterinary remedies in Nhema communal area are indigenous to Zimbabwe (78\%), and the remainder are exotic (Figure 2B). Leaves were the plant parts most frequently used, constituting 51\%, followed by bark (16\%), root $(13 \%)$, fruit (10\%), sap (6\%) and whole plant (3\%) (Figure 2C). The plants reported in this study were used as single plant decoctions or infusions for dosing animals or crushed and used topically for septic wounds.

The most important ethno-veterinary plant species were: Aloe chabaudii (UV $=0.69)$, Aloe greatheadii $(\mathrm{UV}=0.65)$, Adenium multiflorum (UV = 0.63), Vernonia amygdalina $(\mathrm{UV}=0.61)$, Nicotiana tabacum $(\mathrm{UV}=56)$, Solanum lycopersicum $(\mathrm{UV}=$ 55), Capsicum annum (UV = 53) and Pouzolzia hypoleuca $(\mathrm{UV}=51)$. Mwale et al. (2005) examined use of ethno-veterinary remedies in southern Zimbabwe and found Aloe plant to be the most commonly used herb in rural poultry management. Similarly, in South 
Publisher: African Networks on Ethnomedicines

Web page: /http://journals.sfu.ca/africanem/index.php/ajtcam/index

http://dx.doi.org/10.4314/ajtcam.v9i3.3

Africa, Aloe greatheadii is used against internal parasites and eye infections in chickens (Van der Merwe et al., 2001). According to a study carried out in western Kenya, Aloes were found to be the most commonly used herb in communal poultry management, mostly in the treatment of a diarrhoeal diseases (Okitoi et al., 2007). The antimicrobial activities of Aloe chabaudii against positive bacteria (Staphylococcus aureus, Bacillus substilis), gram negative bacteria (Escherichia coli, Salmonella typhimurium, S. gallinarum, Klebsiella sp., Proteus sp.) and Candida albicans have been documented (Mbanga et al., 2010). Chavhunduka (1976), also found the bulb of Adenium multiflorum to be used as a remedy for sore eyes in chickens, decoctions of Capsicum annum fruits and leaves of Nicotiana tabacum as ethno-veterinary remedy for respiratory problems in chickens.

The livestock diseases treated with the highest number of ethno-veterinary plant remedies were diarrhoea ( 9 plant species), eye problems ( 5 plant species), endoparasites (4 plant species) and septic wounds ( 3 plant species). Demand was found to be high for those plant species used for highly problematic livestock diseases such as diarrhoea, fleas, foot rot, retained afterbirth, septic wounds and ticks. Similarly, Matekaire and Bwakura (2004), observed high levels of botanical and veterinary consistency in ethno-veterinary

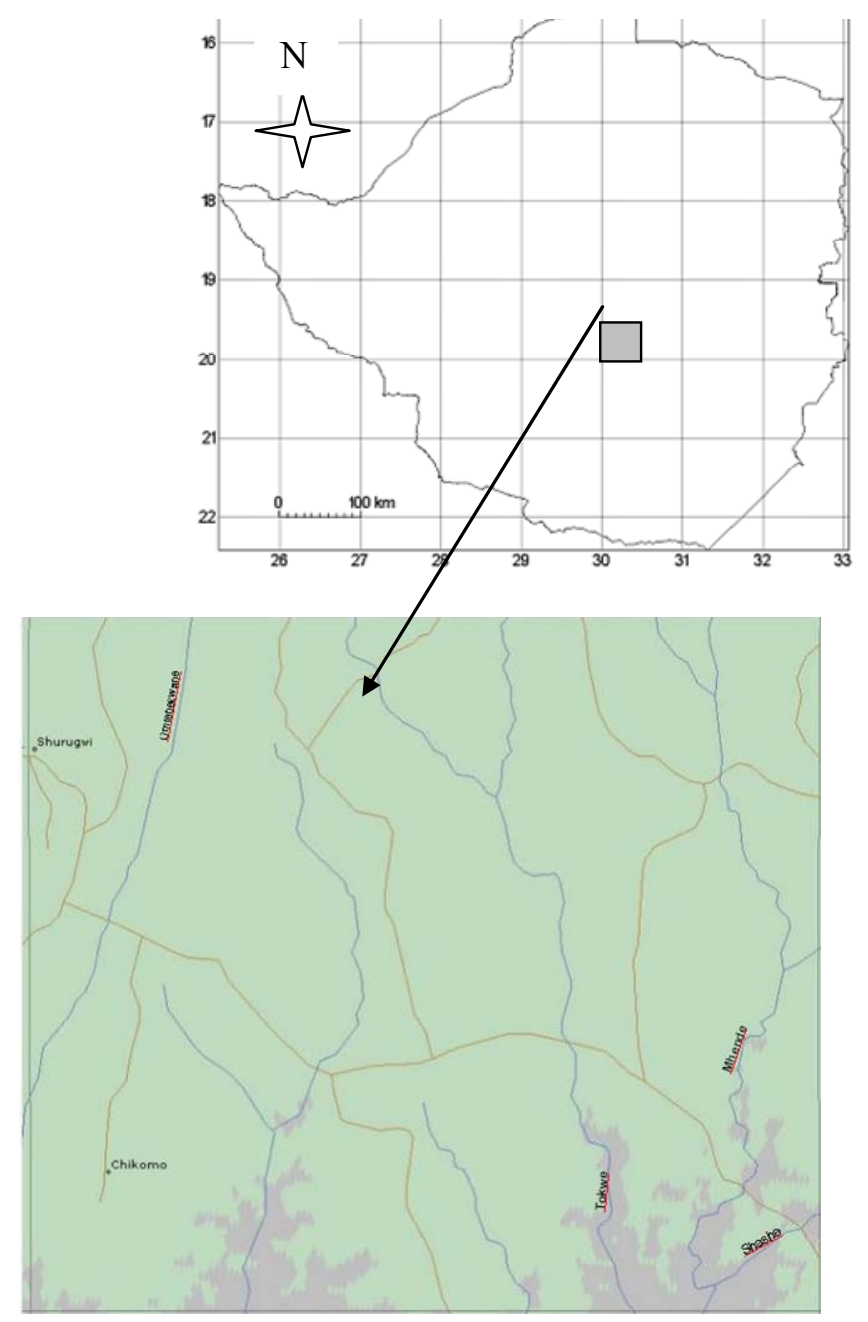

Figure 1: Geographical location of the study area. Top: Map of Zimbabwe illustrating the geographical position of Nhema communal area. Bottom: Detailed map of study area. 
Publisher: African Networks on Ethnomedicines

Web page: /http://journals.sfu.ca/africanem/index.php/ajtcam/index

http://dx.doi.org/10.4314/ajtcam.v9i3.3

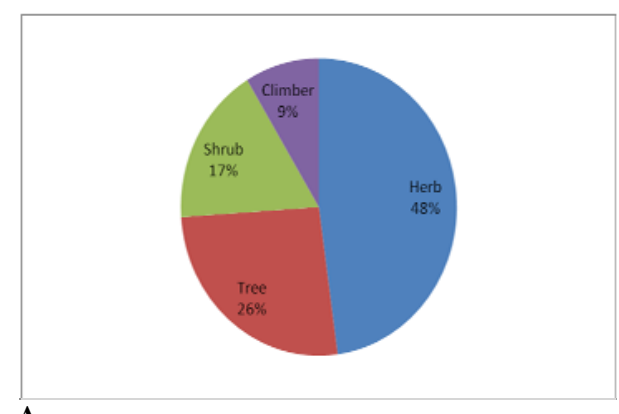

A

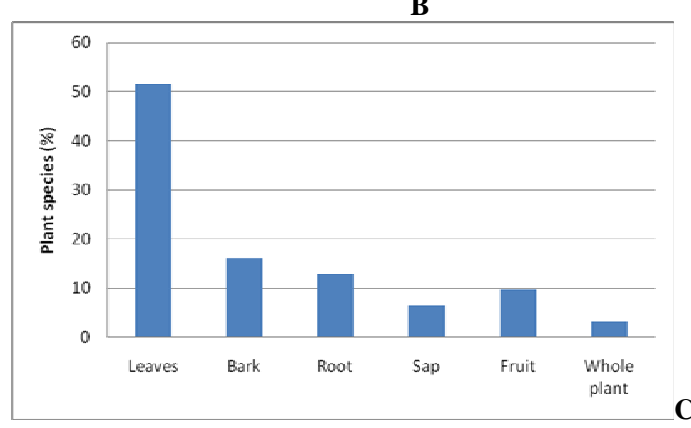

Figure 2: Characteristics of the plants used as ethno-veterinary medicines in Nhema communal area $(n=23)$. (A) growth habit, (B) status of origin, (C) plant part used

Table 1: Demographic characteristics of the respondents in Nhema communal area.

\begin{tabular}{|l|l|l|l|l|l|l|l|l|l|l|}
\hline Characteristic & Female (39\%) & Male (61\%) \\
\hline \multirow{2}{*}{ Age (Years) } & $<20$ & $21-40$ & $41-60$ & $>61$ & Total & $<20$ & $21-40$ & $41-60$ & $>60$ & Total \\
\cline { 2 - 9 } & 2 & 5 & 13 & 7 & $\mathbf{2 7}$ & 6 & 14 & 17 & 5 & $\mathbf{4 2}$ \\
\hline \multicolumn{7}{|c|}{ Livestock ownership } \\
\hline \multicolumn{7}{|l|}{} \\
\hline Livestock & Number of livestock & Percentage (\%) & Number of livestock & Percentage (\%) \\
\hline Cattle & 42.9 & 181 & 57.1 \\
\hline Donkeys & 136 & 34.6 & 51 & 65.4 \\
\hline Goats & 27 & 52.4 & 98 & 47.6 \\
\hline Chicken & 108 & 63.8 & 148 & 36.2 \\
\hline Sheep & 261 & 53.3 & 7 & 46.7 \\
\hline Guinea fowl & 8 & 70.3 & 19 & 29.7 \\
\hline Pigeon & 45 & 64.3 & 71 & 35.7 \\
\hline Turkeys & 128 & 59.3 & 11 & 40.7 \\
\hline Rabbits & 16 & 55.6 & 4 & 44.4 \\
\hline
\end{tabular}

Table 2: Frequency of livestock diseases in Nhema communal area

\begin{tabular}{|l|l|l|l|l|l|l|}
\hline Disease & Cattle (\%) & Donkeys (\%) & Goats (\%) & Chicken (\%) & Sheep (\%) & Rabbits (\%) \\
\hline Diarrhoea & 25 & 13 & 24 & 59 & 9 & - \\
\hline Endoparasites & 21.3 & 6.7 & 28 & 19 & 8 & - \\
\hline Eye problems & 68 & 13.3 & 12 & - & - & - \\
\hline Fleas & - & - & - & 70.7 & - & $42.9 \%$ \\
\hline Footrot & 33.3 & 4 & 54.7 & - & 52 & - \\
\hline Fractures & - & - & 22.7 & - & 10.7 & - \\
\hline General weakness & 13.3 & - & - & 21.3 & - & - \\
\hline Lice & - & - & - & 28 & - & $57.1 \%$ \\
\hline New castle & - & - & - & 33.3 & - & - \\
\hline Respiratory problems & - & - & - & 28 & - & - \\
\hline Retained afterbirth & 56 & - & 16 & - & - & - \\
\hline Septic wounds & 21.3 & 6.7 & 24 & - & 8 & - \\
\hline Snake bite & - & - & 18.7 & - & - & - \\
\hline Ticks & 81.3 & 10.1 & 34.7 & - & 12.3 & - \\
\hline
\end{tabular}


Publisher: African Networks on Ethnomedicines

Web page: /http://journals.sfu.ca/africanem/index.php/ajtcam/index

http://dx.doi.org/10.4314/ajtcam.v9i3.3

Table 3: Ethnoveterinary uses of plant species in Nhema communal area, their habit, use values, disease treated, plant parts used, and mode of preparation and administration. Species marked with an asterisk $\left(^{*}\right)$ are exotics.

\begin{tabular}{|c|c|c|c|c|c|}
\hline $\begin{array}{l}\text { Scientific, local name and } \\
\text { voucher number }\end{array}$ & Habit & UV & Disease & Part used & Preparation and administration \\
\hline \multicolumn{6}{|l|}{ Asphodelaceae } \\
\hline \multirow{5}{*}{$\begin{array}{l}\text { Aloe chabaudii; Gavakava; } \\
\text { AM } 316\end{array}$} & \multirow[t]{5}{*}{ Herb } & \multirow[t]{5}{*}{0.69} & Diarrhoea & Leaves & Infusion made and given by drench \\
\hline & & & Ectoparasites & Leaves & Animal washed with infusion \\
\hline & & & $\begin{array}{l}\text { General } \\
\text { weakness }\end{array}$ & Leaves & Infusion put in drinking water \\
\hline & & & $\begin{array}{l}\text { Respiratory } \\
\text { infections }\end{array}$ & Leaves & Infusion put in drinking water \\
\hline & & & Septic wounds & Leaves & Dry leaves are crushed and the powder applied \\
\hline \multirow{5}{*}{$\begin{array}{ll}\text { Aloe } & \text { greatheadii; } \\
\text { Gavakava; AM } 291\end{array}$} & \multirow[t]{5}{*}{ Herb } & \multirow[t]{5}{*}{0.65} & Diarrhoea & Leaves & Infusion put in drinking water \\
\hline & & & Ectoparasites & Leaves & Bird dipped into infusion \\
\hline & & & $\begin{array}{l}\text { General } \\
\text { weakness }\end{array}$ & Leaves & Infusion put in drinking water \\
\hline & & & $\begin{array}{l}\text { Respiratory } \\
\text { infections }\end{array}$ & Leaves & Infusion put in drinking water \\
\hline & & & Septic wounds & Leaves & Dry leaves are crushed and the powder applied \\
\hline \multicolumn{6}{|l|}{ Apocynaceae } \\
\hline $\begin{array}{l}\text { Adenium } \quad \text { multiflorum; } \\
\text { Chisvosve; AM } 296\end{array}$ & Shrub & 0.63 & Eye problems & Sap & Sap rubbed above animal's eye lid \\
\hline \multicolumn{6}{|l|}{ Asclepiadaceae } \\
\hline \multirow{2}{*}{$\begin{array}{l}\text { Sarcostemma viminale; } \\
\text { Rusungwe; AM } 316\end{array}$} & \multirow[t]{2}{*}{ Climber } & \multirow[t]{2}{*}{0.29} & Diarrhoea & Stem & Animal made to drink stem powder and water mixture \\
\hline & & & Endoparasites & Stem & Animal made to drink stem powder and water mixture \\
\hline \multicolumn{6}{|l|}{ Asteraceae } \\
\hline \multirow[t]{3}{*}{$\begin{array}{l}\text { Vernonia amygdalina; } \\
\text { Muzhozho; AM } 304\end{array}$} & \multirow[t]{3}{*}{ Shrub } & \multirow[t]{3}{*}{0.61} & Endoparasites & Leaves & $\begin{array}{l}\text { Animal made to drink crushed leaves, soot and water } \\
\text { mixture }\end{array}$ \\
\hline & & & $\begin{array}{l}\text { General } \\
\text { weakness }\end{array}$ & Leaves & $\begin{array}{l}\text { Animal made to drink crushed leaves, soot and water } \\
\text { mixture }\end{array}$ \\
\hline & & & $\begin{array}{l}\text { Respiratory } \\
\text { problems }\end{array}$ & Leaves & $\begin{array}{l}\text { Animal made to drink crushed leaves, soot and water } \\
\text { mixture }\end{array}$ \\
\hline \multicolumn{6}{|l|}{ Chrysobalanaceae } \\
\hline $\begin{array}{l}\text { Parinari } \quad \text { curatellifolia; } \\
\text { Muchakata; AM } 297\end{array}$ & Tree & 0.24 & Diarrhoea & Bark & Animal made to drink bark powder and water mixture \\
\hline \multicolumn{6}{|l|}{ Commelinaceae } \\
\hline $\begin{array}{l}\text { Aneilema hockii; } \\
\text { Rutapatsikidzi; AM } 305\end{array}$ & Herb & 0.23 & Fleas & $\begin{array}{l}\text { Whole } \\
\text { plant }\end{array}$ & $\begin{array}{l}\text { Branches of plant are placed near sleeping animals. Fleas } \\
\text { are attracted by the herb and leave the animal. }\end{array}$ \\
\hline \multicolumn{6}{|l|}{ Euphorbiaceae } \\
\hline $\begin{array}{l}\text { Pseudolachnostylis } \\
\text { maprouneifolia; } \\
\text { Mushozhiwa; AM } 315\end{array}$ & Tree & 0.33 & Footrot & $\begin{array}{l}\text { Leaves, } \\
\text { bark }\end{array}$ & Infusion taken by mouth \\
\hline \multicolumn{6}{|l|}{ Fabaceae } \\
\hline $\begin{array}{l}\text { Albizia amara; Muwora; } \\
\text { AM } 292\end{array}$ & Tree & 0.36 & Diarrhoea & Bark & Animal made to drink bark powder and water mixture \\
\hline $\begin{array}{l}\text { Neorautanenia mitis; } \\
\text { Garimanyemba; AM } 295\end{array}$ & Climber & 0.37 & $\begin{array}{ll}\text { To } & \text { de-tick } \\
\text { animals }\end{array}$ & Tuber & Animals washed with infusion \\
\hline $\begin{array}{l}\text { Pterocarpus angolensis; } \\
\text { Mubvamaropa; AM } 314\end{array}$ & Tree & 0.40 & Sore eyes & Sap & Dropped into eyes \\
\hline $\begin{array}{l}\text { Xeroderris stuhlmannii; } \\
\text { Murumanyama; AM } 306\end{array}$ & Tree & 0.39 & Diarrhoea & Bark & Animal made to drink crushed leaves and water mixture \\
\hline \multicolumn{6}{|l|}{ Moraceae } \\
\hline $\begin{array}{l}\text { Ficus burkei; Mushavhi; } \\
\text { AM } 487\end{array}$ & Tree & 0.33 & Diarrhoea & Root & Animal made to drink root powder and water mixture \\
\hline \multicolumn{6}{|l|}{ Musaceae } \\
\hline \multirow{2}{*}{$\begin{array}{l}\text { *Musa } \quad \times \text { paradisiaca; } \\
\text { Mubanana; AM } 311\end{array}$} & \multirow[t]{2}{*}{ Herb } & \multirow[t]{2}{*}{0.43} & Endoparasites & Root & Animal made to drink root powder and water mixture \\
\hline & & & Snake bite & Root & Animal made to drink root powder and water mixture \\
\hline \multicolumn{6}{|l|}{ Myrothamnaceae } \\
\hline $\begin{array}{l}\text { Myrothamnus flabellifoilius, } \\
\text { Mufandichimuka; AM } 313\end{array}$ & Herb & 0.21 & Diarrhoea & Root & Animal made to drink root powder and water mixture \\
\hline Orchidaceae & & & & & \\
\hline $\begin{array}{l}\text { Bulbophyllum sp.; Batanai, } \\
\text { AM } 312\end{array}$ & Herb & 0.31 & Fractures & Bark & Bark is tied around fracture as supporting pad \\
\hline
\end{tabular}


Publisher: African Networks on Ethnomedicines

Web page: /http://journals.sfu.ca/africanem/index.php/ajtcam/index

http://dx.doi.org/10.4314/ajtcam.v9i3.3

\begin{tabular}{|c|c|c|c|c|c|}
\hline \multicolumn{6}{|l|}{ Pedaliaceae } \\
\hline $\begin{array}{l}\text { Sesamum angustifolius; } \\
\text { Gusha; AM } 294\end{array}$ & Herb & 0.27 & $\begin{array}{l}\text { Newcastle } \\
\text { disease }\end{array}$ & Fruit & Animal made to drink crushed fruit and water mixture \\
\hline \multicolumn{6}{|l|}{ Rubiaceae } \\
\hline $\begin{array}{ll}\text { Psydrax } & \text { livida; } \\
\text { Muvengahonye; AM } 402\end{array}$ & Shrub & 0.35 & Septic wounds & Leaves & Fresh leaves are ground, water added and paste put wound \\
\hline \multicolumn{6}{|l|}{ Solanaceae } \\
\hline $\begin{array}{l}\text { *Capsicum } \\
\text { Mhiripiri; AM } 408\end{array}$ & Herb & 0.53 & Diarrhoea & Fruit & Animal made to drink crushed fruit and water mixture \\
\hline \multirow[t]{4}{*}{$\begin{array}{ll}* \text { Nicotiana } & \text { tabacum; } \\
\text { Fodya; AM } 404 & \end{array}$} & \multirow[t]{4}{*}{ Herb } & \multirow[t]{4}{*}{0.56} & Endoparasites & Leaves & $\begin{array}{l}\text { Snuff mixed with soot is given to the animal in drinking } \\
\text { water }\end{array}$ \\
\hline & & & Eye problems & Leaves & $\begin{array}{l}\text { Snuff mixed with soot and infusion of this is dropped into } \\
\text { eyes }\end{array}$ \\
\hline & & & $\begin{array}{l}\text { General } \\
\text { weakness }\end{array}$ & & $\begin{array}{l}\text { Snuff mixed with soot is given to the animal in drinking } \\
\text { water }\end{array}$ \\
\hline & & & $\begin{array}{l}\text { Respiratory } \\
\text { problems }\end{array}$ & & $\begin{array}{l}\text { Snuff mixed with soot is given to the animal in drinking } \\
\text { water }\end{array}$ \\
\hline $\begin{array}{l}\text { *Solanum anguivi; } \\
\text { Nhundurwa; AM } 407\end{array}$ & Herb & 0.20 & Eye problems & Fruit & Fruit is crushed, fluid applied to the eye \\
\hline $\begin{array}{l}\text { *Solanum lycopersicum; } \\
\text { Mutomatisi; } 405\end{array}$ & Herb & 0.55 & Eye problem & Leaves & Animal made to drink crushed leaves and water mixture \\
\hline \multicolumn{6}{|l|}{ Urtiacaceae } \\
\hline \multirow[t]{2}{*}{$\begin{array}{l}\text { Pouzolzia } \quad \text { hypoleuca; } \\
\text { Munhanzva; AM } 409\end{array}$} & \multirow[t]{2}{*}{ Shrub } & \multirow[t]{2}{*}{0.51} & $\begin{array}{l}\text { Gaseous } \\
\text { stomach }\end{array}$ & Leaves & Animal made to drink crushed leaves and water mixture \\
\hline & & & $\begin{array}{l}\text { Retained } \\
\text { afterbirth }\end{array}$ & Leaves & $\begin{array}{l}\text { Fresh leaves are crushed and the slippery paste inserted into } \\
\text { the vagina. }\end{array}$ \\
\hline
\end{tabular}

remedies used for septic wounds, helminthes, retained afterbirth, eye problems, delayed parturition and fractures. Such high demand for plant species such as Aloe sp., Adenium multiflorum, Aneilema hockii, Bulbophyllum sp., Pouzolzia hypoleuca and Vernonia amygdalina calls for sustainable utilization of such important plant species. The great majority of these plant species are collected from the wild and this is likely to continue as the principal source of most ethnoveterinary remedies.

\section{Conclusions}

Ethno-veterinary medicine is still widely practiced among the people of Nhema communal area alongside conventional veterinary medicine. Ethno-veterinary remedies are used to treat different livestock health problems using homemade herbal remedies and various manipulative techniques which include the use of soot. This indigenous knowledge among the locals has accumulated through observation and real life experiences. Such indigenous practices can contribute much for national drug development if it receives the attention it deserves in development programmes. It is also important to standardize the drug preparation, dilution, dosage and route of administration, so as to match conventional procedures. However, the efficacy of these traditional treatments is still open to question, so it is important to carry out further research to confirm the respondents' claims. Ethno-veterinary remedies are important and widely used in Nhema communal area, and more research is desirable on their active compounds, some of which have already shown interesting pharmacological activities. However, there is need for more research on the link between their activity and particular compounds responsible for their wide use as ethno-veterinary remedies. The enormous demand for ethno-veterinary remedies, leaves, bark and roots mean that the wild plant populations are being depleted at a high rate. It appears that the exploitation of wild plants for ethno-veterinary remedies is unsustainable in some cases and might threaten the viability of local plant populations. Therefore, better collection methods, for example use of leaves, fruits, flowers rather than whole plants, roots and bark are recommended. The mid-term and long-term solution to the local needs involve cultivation of some of the plant species in home gardens.

\section{Acknowledgements}

I would like to thank the people of Nhema communal area for their assistance and cooperation during data collection. I am grateful to Dr A. Muroyiwa for reviewing earlier drafts of this paper. Thanks to Antony Mapaura, National Herbarium and Botanic Gardens, Harare for preparing the distribution map of the study area.

\section{References}

1. Bridson, D. and Foreman, L. (1998). The herbarium handbook. $3^{\text {rd }}$ edition. Royal Botanic Gardens, Kew, Richmond, United Kingdom.

2. Chavunduka, D.M. (1976). Plants regarded by Africans as being of medicinal value to animals.

Rhod. Vet. J. 7: 7-13.

3. Dold, A.P. and Cocks, M.L. (2001). Traditional veterinary medicine in the Alice district of the Eastern Cape province, South Africa.

S. Afr. J. Sci. 97: 375-379. 
Publisher: African Networks on Ethnomedicines

Web page: /http://journals.sfu.ca/africanem/index.php/ajtcam/index

http://dx.doi.org/10.4314/ajtcam.v9i3.3

4. Gelfand, M., Drummond, R.B., Mavi, S. and Ndemera, B. (1985). The traditional medical practitioner in Zimbabwe: His principles of practice and pharmacopoeia. Mambo Press, Gweru.

5. Grandin, B.E. (1988). Wealth ranking in smallholder communities: A field manual. Intermediate Technology Publication, London.

6. Grant, P.M. (1981). The fertilization of sandy soils in peasant agriculture. Zim. Agr. J. 78: 169-175.

7. Holmgren, P.K. and Holmgren, N.H. (2004). Index herbariorum. [accessed 3 January 2011]. Available from: http://www.nybg.org.

8. Jabbar, A., Akhtar, M.S, Muhammad, G. and Lateef, M. (2005). Possible role of ethnoveterinary medicine in poverty reduction in

Pakistan: Use of botanical Anthelmintics as an example. J. Agric. Soc. Sci. 1(2):187-195.

9. King, S.R. and Carlson, T. (1995). Biocultural diversity, biomedicine and ethnobotany: the experience of Shaman Pharmaceuticals. Journal of Science and Technology of the Americas 20: 134-139.

10. King, S.R. and Tempesta, M.S. (1994). From Shaman to human clinical trials: the role of industry in ethnobotany, conservation and community reciprocity. In: Chadwick, D.J. \& J. Marsh (eds), Ethnobotany and the search for new drugs. Ciba Foundation Symposium 185. John Wiley and Sons Chichester/New York pp. 197-213.

11. Maine, V.A.C., Lívia, E.T.M., José, S.M. and Rômulo, R.N.A. (2009). Animals to heal animals: ethnoveterinary practices in semiarid region, Northeastern Brazil. J. Ethnobiol. Ethnomed. 5:37. doi:10.1186/1746-4269-5-37

12. Martin, G.J. (1995). Ethnobotany: A methods manual. People and Plants Conservation Manuals Volume 1. Chapman and Hall, London.

13. Matekaire, T. and Bwakura, T.M. (2004). Ethnoveterinary medicine: A potential alternative to orthodox animal health delivery in Zimbabwe. Int. J. Appl. Res. Vet. Med. 2(4): 269-273.

14. Matekaire, T., Mupangwa, J.F. and Kanyamura, E.F. (2005). The Efficacy of Banana Plant (Musa paradisiaca) as a Coccidiostat in Rabbits. Int. J. Appl. Res. Vet. Med. 3: 326-331.

15. Mathius-Mundy, E. and McCorkle, C.M. (1989). Ethnoveterinary medicine: an annotated bibliography. Bibliographies in Technology and Social Change, No 6: 199 Technology and Social Change Program, Iowa State University, Ames, Iowa 50011, USA.

16. Mbanga, J., Mangoma, N. and Saidi, B. (2010). An Evaluation of the antimicrobial activities of Aloe barbadensis, A. chabaudii and A. arborescens leaf extracts used in folklore veterinary medicine in Zimbabwe. J. Anim. Vet. Adv. 9(23): 2918-2923.

17. McCorkle, C.M. (1986). An introduction to ethnoveterinary research and development. J. Ethnobiol. 6: 129-149.

18. McGaw, L.J. and Eloff, J.N. (2008). Ethnoveterinary use of southern African plants and scientific evaluation of their medicinal properties. J. Ethnopharmacol. 119: 559-574.

19. McGregor, J. (1994). Woodland pattern and structure in a peasant farming area of Zimbabwe: Ecological determinants and present and past use. For. Ecol. Manage. 63: 97-133.

20. Mwale, M., Bhebhe, E. Chimonyo, M. and Halimani, T.E. (2005). Use of herbal plants in poultry health management in the Mushagashe small-scale commercial farming area in Zimbabwe. Int. J. Appl. Res. Vet. Med. 3: 163-170.

21. Mwale, M., Gadzirayi, C.T., Mapiye, C., Nemaunga, M., Kuchenga, M.M. and Mupangwa, J.F. (2007). Use of ethno-veterinary medicine forthe control of cattle parasites by smallholder farmers in Zimbabwe. S. Afr. J. Educ. Sci. Techn. 1 (2): 111-117.

22. Njoroge, G.N. and Bussmann, R.W. (2006). Herbal usage and informant consensus in ethnoveterinary management of cattle diseases among the Kikuyus (Central Kenya). J. Ethnopharmacol. 108: 332-339.

23. Norusis, M.J. (1988). Scientific package for social scientists user guide. 3rd edition. Chicago: SPSS Incl.

24. Okitoi, L.O., Ondwasy, H.O., Siamba, D.N. and Nkurumah, D. (2007). Traditional herbal preparations for indigenous poultry health management in Western Kenya. LRRD 19. [accessed 3 January 2011]. Available from: http://www.Irrd.org/Irrd19/5/okit19072.htm.

25. Phillips, O., Gentry, A.H., Reynel, C., Wilki, P. and Gávez-Durand, C.B. (1994). Quantitative ethnobotany and Amazonian conservation. Conserv. Biol. 8: 225-248.

26. Shen, S., Qian, J. and Ren, J. (2010). Ethnoveterinary plant remedies used by Nu people in NW Yunnan of China. J. Ethnobiol.

Ethnomed. 6:24. doi:10.1186/1746-4269-6-24

27. SPSS Inc. (1999). SPSS version 10. SPSS Incl., Chicago, Illinois, USA.

28. Tamboura, H.H., Sawadogo, L.L., Kaboré, H. and Yameogo, S.M. (2000). Ethnoveterinary medicine and indigenous pharmacopoeia of Passoré Province in Burkina Faso. Ann. N Y. Acad. Sci. 916: 259-264.

29. Tabuti, J.R.S., Dhillion, S.S. and Lye, K.A. (2003). Ethnoveterinary medicines for cattle (Bos indicus) in Bulamogi county, Uganda: plant species and mode of use. J. Ethnopharm: 279-286.

30. Van der Merwe, D., Swan, G.E. and Botha, C.J. (2001). Use of ethnoveterinary medicinal plants in cattle by Setswana-speaking people in the Madikwe area of the North West Province of South Africa. J. S. Afr. Vet. Assoc. 72: 189-196.acol. 88

31. Victor, J.E., Koekemoer, M., Fish, L., Smithies, S.J. and Mössmer, M. (2004). Herbarium essentials: the southern African herbarium user guide. SABONET Report No. 25. Pretoria, 93pp.

32. Whitlow, J.R. (1980). Deforestation in Zimbabwe. Zambezia (Suppl.), University of Zimbabwe, 66 pp.

33. Wild, H. and Barbosa, L.A. (1968). Vegetation map of the Flora Zambesiaca area. Supplement to Flora Zambesiaca M.O. Collins, Salisbury. 